\title{
THE FIXATION SUPPRESSION OF CALORIC NYSTAGMUS AND OCULOMOTOR FUNCTIONS
}

\author{
YU SATO AND TADASHI KAWASAKI
}

Department of Physiology, School of Medicine, Toyama Medical and

Pharmaceutical University, Toyama

ISAO KATO

Department of Otolaryngology, School of Medicine, Yamagata University, Zao-Iida

$$
\text { KANEMASA MIZUKOSHI }
$$

Department of Otolaryngology, School of Medicine, Niigata University. Niigata

\section{MAKOTO HAYANO}

Department of Neurosurgery, Brain Research Institute, Niigata University, Niigata

The function of eye movement in 38 cases with various diseases in CNS was examined, and the following findings were obtained. The cases with supratentorial diseases did not show the value less than $50 \%$ of (FS) fixation suppression of caloric nystagmus. But many cases with infratentorial diseases, especially cerebellar diseases, had the value less than $50 \%$ of $\mathrm{FS}$, and those cases showed the high incidence of disturbances of optokinetic nystgmus, eye tracking and lateral gaze. In cases with the value more than $70 \%$ of FS, such disturbances were hardly found. In spontaneous, positional, and positioning nystagmus tests, there was no correlation between the value of FS and the incidence of the disturbances of optokinetie nystagmus, eye tracking and lateral gage. It seems probable that the mechanism of eye fixation and eye tracking is closely related with that of FS.

A $81-0106-10482$

\section{温度性眼振の固視抑制と眼球運動機能について}

\author{
富山医科菻科大学医学部生理学教室 \\ 在藤悠, 川崎匡 \\ 山形大学医学部耳鼻咽喉科学教室 \\ 加藤功 \\ 新潟大学医学部耳粼咽喉科学教室 \\ 水越 銖 理 \\ 新潟大学脳研究所脳神経外科学教室
}

畐野信些

\section{I 緒言}

視觉の関与により温度性眼振が㧕制をらけることは， 一般飞よく知机ている現象であ (Mahoney et al, Alpert ${ }^{2)}$, Molnar and Torok $\left.{ }^{3}\right)$. 中枢神経系疾患例飞
执いて，この抑制が弱まる，又は消失する症例があるこ とも知られている(Coats ${ }^{4}$, Maccario et al. $\left.{ }^{5}\right)$. 今回わ れわれは，中权神経系疾患38例に蛙いて視觉の関与によ

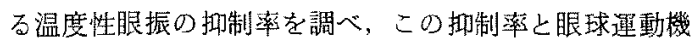


能一特に静止物体の固視機能々移動物体の追跡機能一上 飞相関があるかどうか，定量的な分析を行なってみた．

\section{II 検查対象}

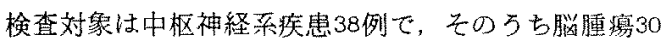
例, 筑血管障害 7 例, 頭部外傷 1 例である. 全例新潟大学 脳神経外科入入院し, 手術又山 computed tomography

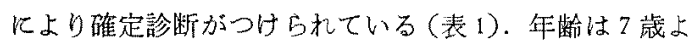
り63歳まで，男性14名，女性24名である，症例番号 13， 19，22，29．30，35，37以術後に，他はすべて術前に檢 查したものである。症例33は病篓がテント上とテント下 の両方にまたがって扣り，テント下に分類した。

\section{表 1 診 断 名}

\section{1. テント聅㭧}

松果体睡㜔

下垂体腚尰

頭蓋咽頭尰

脳動 脈 瘤

㨫動静腺获形

右視床腫曒

星細胞腫

䯣膜腫

神経脍腫

静脈洞血腫

2. テント下族患

\begin{tabular}{|c|c|}
\hline 第口四脳窒腄境 & 21,22 \\
\hline 聴 神経鞘腫 & $23 \sim 29$ \\
\hline 橋 神 経 膠 腫 & 30 \\
\hline 橋 血I 栓 & 31 \\
\hline 左三叉神経粸腫 & 32 \\
\hline 転移性脳腫惕 & 33 \\
\hline 小脳衄管芽腫 & $34 \sim 36$ \\
\hline 小榙 䯣膜腫 & 37 \\
\hline 頍 部 外 伤 & 38 \\
\hline
\end{tabular}

\section{III 検查方法}

検查方法， Electronystagmography 八の記録力法共

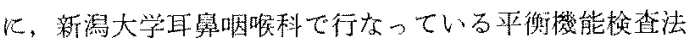
(Mizukoshi et al. ${ }^{63}$ ) K濩じ以下の頊目について检查し た.

1) 視觉剌激による温度性眼振排制の検查

温度性眼振解発方法は Fitzgerald and Hallpike ${ }^{\gamma}$ ( 㤎法 (大谷 $\left.{ }^{8}\right) K$, 温度性眼振抑制方法は Kato et al.
の Test condition III and VK，温度性眼振の抑制犁の 算定方法は Takemori and Cohen ${ }^{109}$ 亿従った。

a) 固視条件炕らる温度性眼振への抑制效果

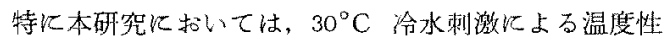

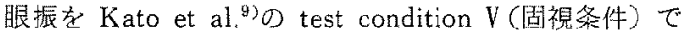
㧕制した場合の抑制率在右耳て平均して FS (6xation

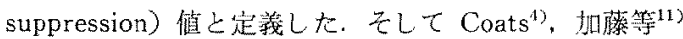

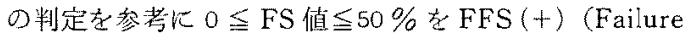
of Fixation Suppression of caloric nystagmus), $50<$

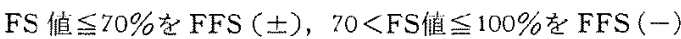
上判定した.

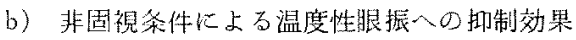

Kato et al. ${ }^{9} の$ test condition II (非固視条件) での 㧕制摔 VS (Visual Suppression) 值と定義した。

2) 視速動栍眼振検祖

視理動性眼振の解発方法は Mizukoshi et al. ${ }^{6}$ K㹱 い, 眼振反心の判定は石川 ${ }^{12}$ の判定基準に従った. 本研 笢では，総眼振数上適空限界速度 $(\mathrm{OAL})$ 学測定し，水

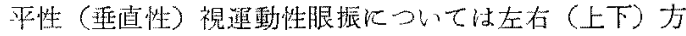

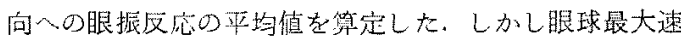
度の湘定络次の理白で削除した。すな⿰力口。，視角 20 度

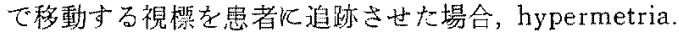
hypometria を生し，眼球偏位角度は20度にはならな い.このため輍正時の誤差が大きくなると思われた。

\section{3）視標追跡検査}

$0.3 \mathrm{~Hz}$ の正弦波運動をする視標を眼前 $100 \mathrm{~cm}$ ，視刍 20 度で追跡させ， smooth pursuit t正常， saccadic pattern, ataxic pattern を異常上判定した (Benite $z^{13)}$.

4) 注䘽眼振検查

5) 刍発眼振检湘

6）頭位眼振検查

4）５，6)については眼振が諗められたものを異常と 判定した。

7) 頍位変揬眼振㮔查 (stenger 法) 釷直性眼拔が認められたものを珙常と判定した。

\section{N 㭘 查成續}

1) FS 值乞病梁局在乞の関係

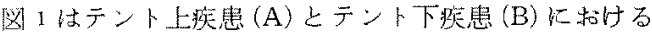
FS 值の分布を示した香のである。テント上族患では FFS (+) 例は認められず, FFS(土) 例が 3 例, FFS(一) 例が 17 例て，FFS (-) 例が大多数占めた。これと刘 照的飞，テント下疾患ではFFS(+)例汃 4 例，FFS.(土) 例が 8 例, FFS $(-)$ 例が 6 例で, $\operatorname{FFS}(+),( \pm)$ 例が多 
かった。テント下疾患の内でも，病柴が小脳仅限局して いる例(症例34〜37) では FFS (+) が 2 例, FFS (土) が 1 例, FFS (-)が 1 例で，小脳疾㭧例飞高率飞FFS(+)，

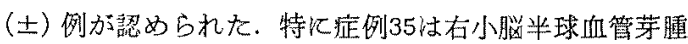
例で右问きの温度性眼振に括いて固視抑制解除現象がみ

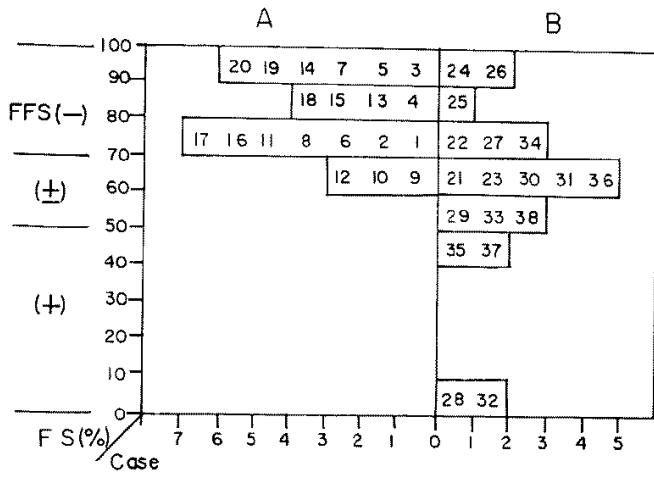

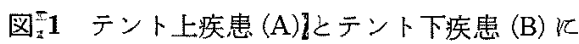
嘫けるFS 值の分有. グラフ内の数字は症例 番号在示す

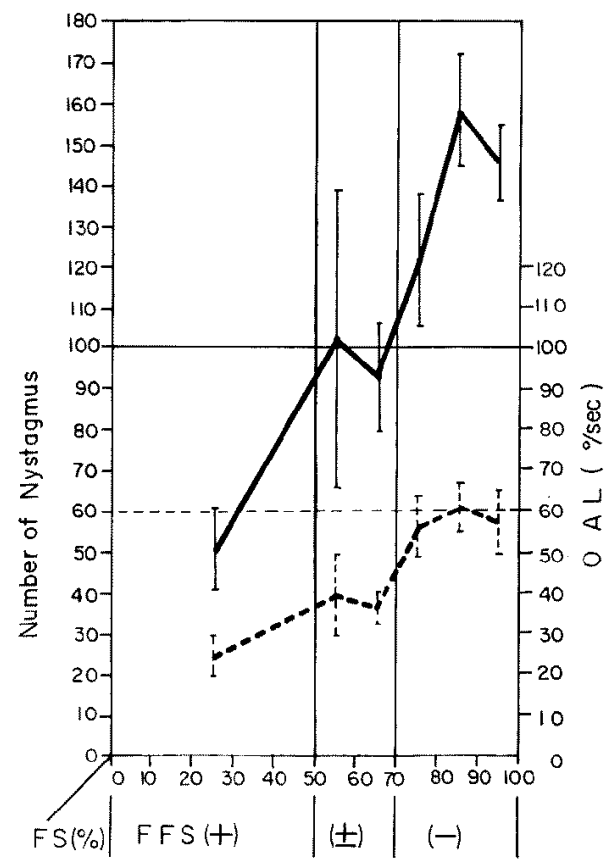

図 2 FS 值と水平性視運動性眼振との関係，奏 線は眼振数, 破線は OAL 值で平均值之標染詰 差を示す 石川12) によると正常值は眼振数 100 以上，OAL值 $60 \% \mathrm{sec}$ 以上となっている。
られた，症例36は左小脑半球血管芽腫例で左向きの温度

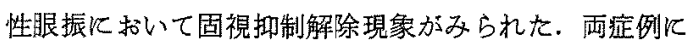
特ける㓯制解除の方向性は Takemori and Cohen ${ }^{10)}$ の サルを使った夷驗結果上一致するものである，雨症例飞 括いては障害側と反対方向八向かろ視盗動性眼振の障害

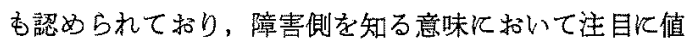
する所見と思われる，末たテント下疾患の内でも病巣が 脳幹部化局しているとみられる10定例（症例23～32） では FFS(十)が2例, FFS(士)が 4 例, FFS(一)が 4 例認められた，以上のごとく，本研究比括いては，小脳 疾患例，脳幹障害例に和いて FFS (+)が認められた。

2) FS 值と視荤動性眼振との関係

图 2 はFS 值と水平性視運動性眼振の成績を示したも のであるＦS 值が隇少するにとすない，眼振数，OAL 值毛隇少することがわかる，FFS（一）群では，眼振数， OAL 值は，ほほ正常值 (眼振数は100以上，OAL值は 60 度/秒以上，石川 ${ }^{12)}$ ) 老示すが, FFS (十)群では正常 值を大幅化まわっている．FFS(士)群では両者の中間 の値を示している.その值については表2亿示す 各群 の統計処理の絓果では, FFS (十) 群上 (士) 群の間では危 険率 $5 \%$ の水準では有意の差がないと判定された. FFS (十)群之(一) 群, 及ご FFS (土) 群之(一) 群の間では 1\%以下の危険率で有意の差が認められた。すなわち FFS (一) 群では水平性視運動性眼振の解発は正常である が，FFS(十)，(土）群ではこれが障害されていることが 明らかとなった。琹直性視運動性眼振に拈いても，ほほ 同じような結果を得ている。

3) FS 值と他の眼球運動機能検查との関係

図3は視運動性眼振のような定量的測定をすることが 困楼であった他の眼球運動機能検查の成績を，正常，異 常のどちらかに判定し，FS 值に対する翼常率を示した ものである。水平性視標追跡检查（A）と注視眼振検查 (C) では FFS (十)，(士) 群に和いて買常率が高く, FFS

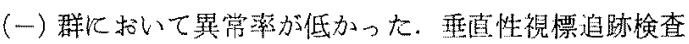

表 2 FFS (十)，(士)，(一) 群に招ける水平性 䘽運動性眼振の検查成績

\begin{tabular}{|c|c|c|c|c|}
\hline & \multicolumn{2}{|c|}{ 眼 振 数 } & \multicolumn{2}{|c|}{ OAL 值 } \\
\hline & 平均值 & 標準洖差 & 平均值 & 標準哭差 \\
\hline $\operatorname{FFS}(+)$ & 50.4 & 10.2 & 24.1 & 4.9 \\
\hline $\mathrm{FFS}( \pm)$ & 95.1 & 12.7 & 37.0 & 3.9 \\
\hline $\operatorname{FFS}(-)$ & 137.6 & 8.8 & 57.4 & 4.5 \\
\hline
\end{tabular}



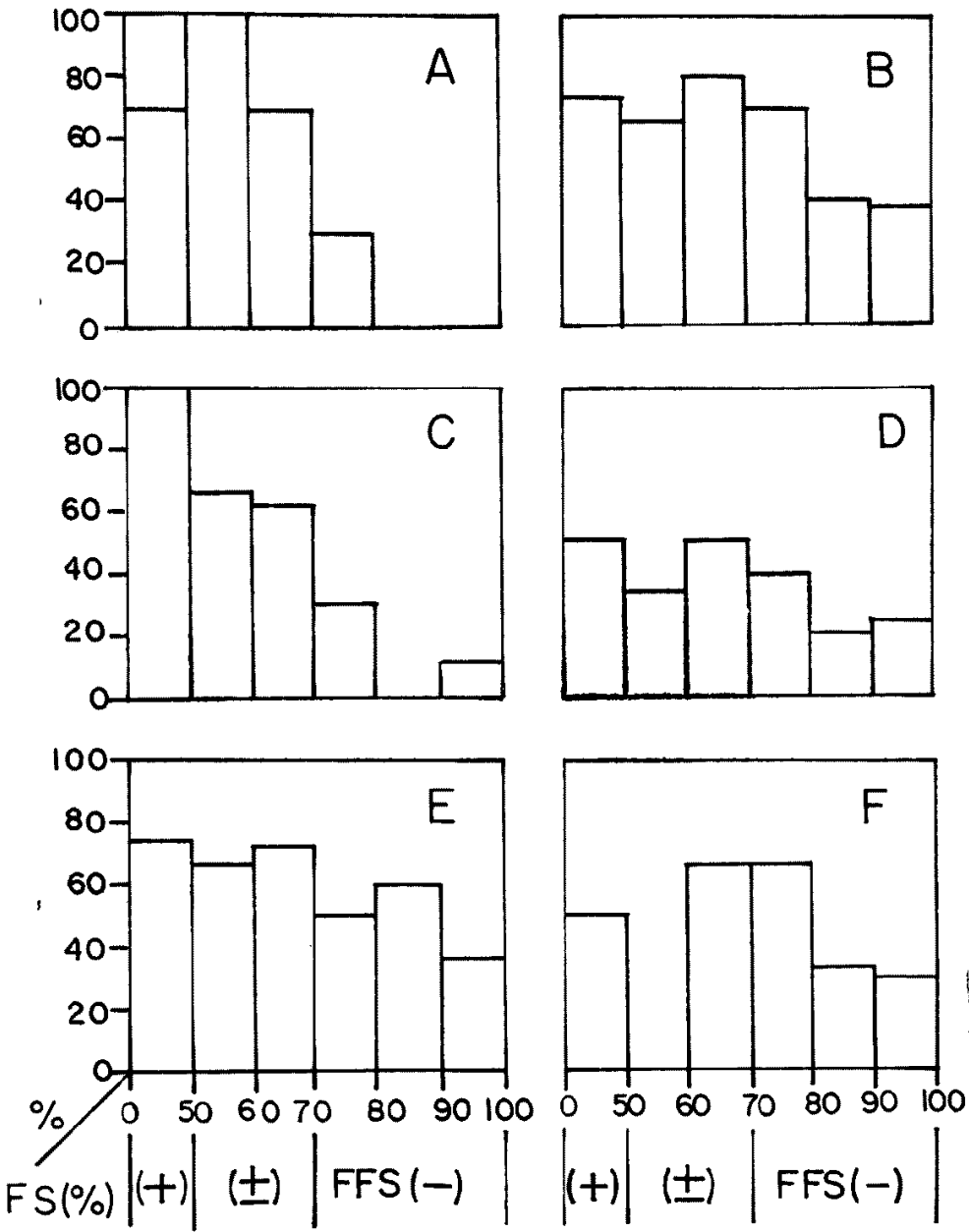

図 3 FS 值と水平性視標追跡検㚗 (A)，垂直性視摽追跡桧查 (B)，注視眼振検查 (C)，自

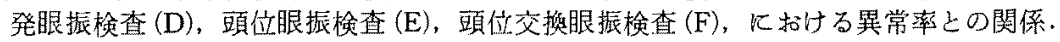

（B）ではどの群で娄翼常率が高かった。一方自発眼振 (D)，頭位眼振 $(\mathrm{E})$ ，頭位変換眼振 (F)心検变で仿，異常 㲎と FS 值の間に相関がみられな加った。つまり FFS $(+) ，( \pm)$ 群では視標道跡のさいK smooth pursuit $の$ 障害があり，注視眼振の発現率が高かった. FFS(一)群 ではこれらの梌查に異常劣認めない例が多かった。一 方, 自発眼振, 頭位眼振, 頭位変換眼振など, 眼球の固 視・追跡機能と関連がないと思われる㭘查では, 検査成 續と FS 值飞関連がないことが瑟められた。

4) VS 值次て

図 4 は非固視条件に扣ける温度性眼振の㧕制率 (VS 值）の分布を示したものである.VS 值は FS 值より非
常低低く，テント上疾患 $(\mathrm{A})$ でもテント下疾患 (B)でも 同じような分乍をしていることがわかる，またVS 值が 30\%以下しかない儿もか力加らず，水平性の視標迫跡， 視運動性眼振, 注視眼振の检查で全く異常を諗めない例 (症例 $2,3,4,6,8,13,15,18$ ) 加多く, VS 值と固 視・追跡機能とに相関が認められなかった。

\section{$V$ 考按}

前㝚動眼反射引は，3つ0神経活動の単位より成り，半 規管への加速度入力は, 前庭神経, 前庭神経核, 眼運動神 経核を伝達して眼筋へ出力している(Ito et al. ${ }^{14)(5) 16) 17)}$ ). 一方，小脸片葉は絧膜より視覚入力を受けて（Maekwa and Simpson ${ }^{18)}$, Maekawa and Takeda ${ }^{19)}$ 前神経 
A

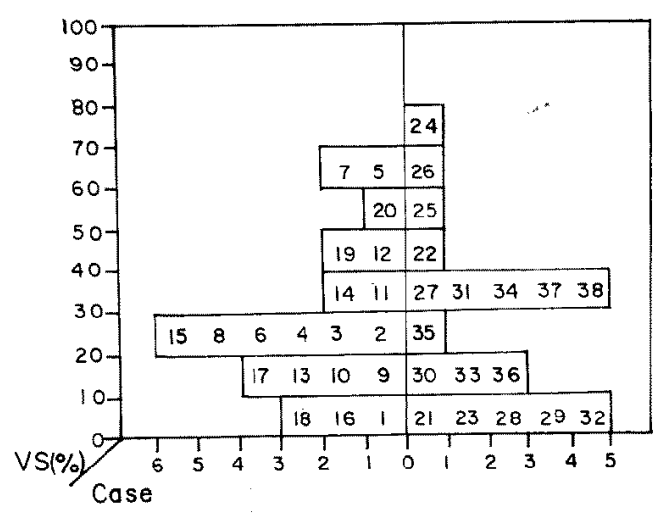

図 4 テント上疾患 (A) とテント下疾患 (B) に 扣けるVS 值の分布, グラフ内の数字は症例 番号走す

核へ接綕している．この2つの神経回路により，小脳片 藻のプルキンエ細胞は前庭种経核の発火頻度老調節し ていらという (Ghelarducci et al. ${ }^{20)}$, Lisberger and

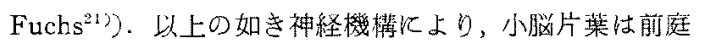
動眼反射の利得 (出力/入力) 調節をしていること加認め bれている(Melvill Jones and Milsum ${ }^{22)}$, Gonshor and Melvill Jones ${ }^{23524)}$, Ito et al. ${ }^{25)}$, Miles and Fuller ${ }^{26)}$, Robinson ${ }^{27)}$ ). この利得調節は，あくまでも物体を固視 しやすいように，すなわち網膜上の像がずれないように 合目的な香のと考光られている，たとえば Tto et al. ${ }^{25}$

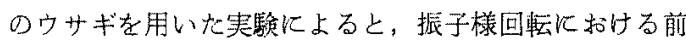
庭動眼反射の利得（出力/入力 $=$ 眼球回転角度/台の回転 角度）は暗所飞括いて約 0.5 であるが，台上同相人動く スリットをみせると利得が下がり，固定スリットをみせ ると利得が上がるという。またこの利得調節作用は小脳 片葉を破壊することによって消头するこしも知られてい る (Ito et al. ${ }^{25}$, Robinson ${ }^{26)}$ ).

ここで正味の前庭趿腿反射の利得るAとするならば， 固視による温度性眼振の抑制率が80\%であるということ は. 利得が0. $2 \times \mathrm{A}$ となったことを意味する。本研祭に 扔いて正常の㧕制率であるとした FFS (一) 群では, 抑 制率は70\%以上である。すなから利得は $0.3 \times \mathrm{A}$ 以下K 調節されているのである。しかし FFS(十)群で性物制 率は50\%以下つまり利得は，0.5×A 以上である。李 わち FFS $(+)$ ¿は利得調䬣能力が弱まった，又心消失 したために利得定 $0.5 \times$ A 以下に下けられなくなった状 態と思玑れる。
本研究飞打いて，温度性眼振の回視㧕制率は眼球の固 視・追跡機能と相関肪子られた。 つまり FFS (+)，(土) 群（利得調節能力が弱まっている群）では視運動性眼振 の解発が墨く, smooth pursuit の障害があり，注視眼 振の発現率が高かった. FFS (一) 群 (利得調節能力が正 常な群)ではこれらの異常は少なかった。また，非固視 条件下での VS 值は，固視条件下でのFS值よりもかな り低く、VS 值は眼球の固視・道跡機能とに相関がなか

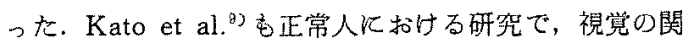
与による温度性眼振の抑制率は固視の程度により影響さ れ，非固視条件は固視条件よりも排制率が低くなること を報告している.Zee et al. $^{28}$ は小畄变性疾患と挌いて。 前庭動服反射の抑压能力の減少量は, smooth pursuit $の$ 障害程度とよく関連していると報告している。これらの 研究事夷及び報告は, 前庭動眼反射の利得調節が単に光 の入力によって行なわれるのではなく，固視・追跡機構 が介入している結果之考えられる.

以上考察したごとく「前庭動眼反射の利得調節は，小 脳片葉が固視及び追跡機構の介入に上り行なっている」 ものと思㹝る。したがって理諭的には FFS (十)とな る原因化次の 2 つの場合が考えられる。第 1 は利德調節 を直接行なっている小慆片葉か障害された場合，第 2 は 眼球の固視・追跡譏槛が障害された場合である。

第 1 の場合は，FFS(十)例で, 視運動性眼振, 注視眼 振，視骠追跡検查儿異常を認めない小脳障害例があって 屯理論的にはよいわけである。ところが本研究に批いて は，FFS (十)，(土)と認めら机大小脳疾患例の全例が 3 種の检查のう方，いずれか炕巽常を認めている。この事 実加ら，小脳片葉自体分固視・追跡機構に関与している と考えられる、これを支持するものとしてはWesheimer and Blair ${ }^{29}$ は小脳除去サルて smooth pursuit と OKN の障管をみると報告している。 Ozawa et al ${ }^{30)}$, Wadia

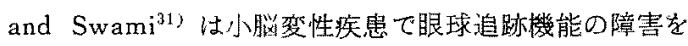
みとる報告している、したがって小脳自体力眼球の国 視・追跡機棰に関与しているものと思われる。

第 20 場合は障害部位のいかんKかかからず固視・道 跡機棈が障害されることにより FFS(十)となりえよう。 しかし本研究に拀いては，小钢障害例の他に，脳幹障害

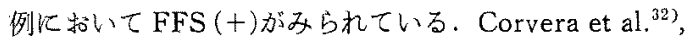
Baloh et al. ${ }^{33)} は$ 脳幹障害例で視運動性眼振, 視標追跡

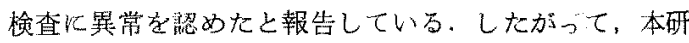
究に招いて，脳幹障害例で FFS (十)がみられたのは， 脳幹障害に上り眼球の固視・逼跡機能が障害され，その 
ため FFS（十となった可能性が考えられる。

\section{II 結 語}

中枢神経系矣患に抋てて, 視賞の関与による温度性眼 振抑制率と眼球運動機能との関連を調へた。そ絬果， 温度性眼振の固視㧕制率の減少度は視運動性眼振の障㸷 度, smooth pursuit の障害率及び注視眼振の出现萃上 相関していた。しかし温度性眼振の固視抑制率は目発。 頭位, 頭位变換眼振の出現率と相関等琶められなか力 た. 一方非固視条件による湿度性眼振の抑制率洁，固視 条件汇よる抑制率江比へかなり低く，固視・追跡機能と も相関がないことが忍められた．以上の事実と文献的㳊 察に上り「前庭動眼反射の利得調節は，眼球の固視・追 跡機構の介入により，小脳片葉が行なっている」ものと 考察した，固視に上る温度性眼振の㧕制解除現象 (FFS (十)とはこの利得蓓節能力が弱まった，又心消失した 状態でする。したがって FFS（十）となるには次の2つ の場合が考えられる。第 1 は直接的索利得調節機構が障 害された場合で、これは小畄片葉が障害された場合にあ たる、第 2 は障害部位のいか儿にかかからず，眼球の固

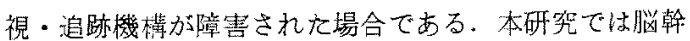
障害例てFFS(+)功羿められて招り，第2 2 場合飞相 当する可能性があるすのと考察した。

\section{文献}

1) Mahoney, J.L., Harlar, W.L. and Bickford, R. $G$.: Visual and other factors influencing caloric nystamus in normal subjects. Arch. Otorayngol., $66 ; 46-53,1957$

2) Alpert, J.N.: Failure of fixation suppression. Neurology, 24; 861-896, 1974.

3) Molnar, E.M. and Torok, N.: The effect of ocular fixation on the caloric nystagmus. ORL, $36 ; 76-84,1974$.

4) Coats, A.C.: Central electronystagmographic abnormalities. Arch. Otolaryngol., 92; 43-53, 1970.

5) Maccario, M., Backman, J.R. and Korein, J.: Paradoxical caloric response in altered states of consciousness. Neurology, 22; 781-789, 1972.

6) Mizukoshi, K., Nagaba, M., Ohno, Y., Ishikawa, K., Aoyagi, M., Watanabe, $Y$. , Kato, I. and Ino, H.: Neurotological studies upon intoxication by organic mercury compound. ORL, 3?;
$74-87,1975$.

7) Fitzgerald, G. and Hallpike, C.S.: Studies in human vestibular function; 1 . Observation on the directional preponderance (Nystagmus beraitschaft) of caloric nystagmus resulting from cerebral lesion. Brain, 65; 115-137, 1942.

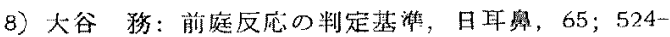
$543,1962$.

9) Kato, I., Kimura, Y., Aoyagi, M., Mizukoshi, $K$, and Kawasaki, T.: Visual suppression of caloric nystagmus in normal individuals. Acta Otolaryngol., 83; 245-251, 1977.

10) Takemori, S. and Cohen, B.: Loss of visual suppression of vestibular nystagmus after flocculus lesions. Brain Res., Amsterdam, 72; 213-224, 1974.

11) 加藤 功，小湖吉郎，青柳 傮，木村 洋，水越鉄 理, 石川和光, 渡辺行雄, 山崎睛子, 俈藤 悠: 開 眼，固視飞上西前庭性腿振への抑制効果检查の診断

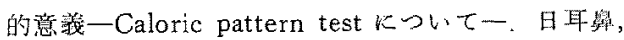
$80 ; 507-514,1977$

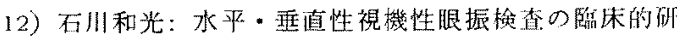

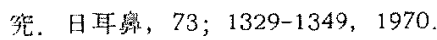

13) Benitez, J.T.: Eye-tracking and optokinetic tests: Diagnostic significance in peripheral and central vestibular disorders. Laryngoscope, 80; 834-848, 1970.

14) Ito, $M$.: Neural disign of the cerebellar motor control system. Brain Res., 40; 81-84, 1972.

15) Ito, $M$. Nishimaru, $N$. and Yamamoto, $M$. The neural pathways mediating reflex contraction of extraocular muscles during semicircular canal stimulation in rabbits. Brain Res., 55; 183-188, 1973.

16) Ito, $M$., Nishimaru, $N$. and Yamamoto, $M$. The neural pathways relaying reflex inhibition from semicular canals to extraocular muscles of rabbits. Brain Res., 55; 189-193, 1973.

17) Ito, M., Nishimaru, $N$. and Yamamoto, M.: Specific neural connections for the cerebellar control of vestibulo-ocular reflexes. Brain Res., $60 ; 238-243,1973$.

18) Maekawa, $K$. and Simpson, J.I.: Climbing fiber 
responses evoked in the vestibulo-ocular responses of rabbit from visual system. J. Neurophy., 36; 649-666, 1973.

19) Maekawa, K. and Takeda, T.: Mossy fiber responses evoked in the cerebellar flocculus of rab* bits by stimulations of the optic pathway. Brain Res., 98; 590-595, 1975.

20) Ghelarducci, B., Ito, M. and Yagi, N.: Impulse discharges from flocculus Purkinje cells of alert rabbits during visual stimulation combined with horizontal head rotation. Brain Res., 87; 66-72, 1975.

21) Lisberger, S.G. and Fuchs, A.F.: Response of flocculus Purkinje cells to adequate vestibular stimulation in the alert monkey: fixation vs. compensatory eye movements. Brain Res., 69; $347-353,1974$.

22) Melvill Jones, G. and Milsum, J.H.: Frequencyresponse analysis of central vestibular unit activity resulting from rotational stimulation of the semicircular canals. J. Physiol,, 219; 191-215, 1971.

23) Gonshor, A. and Melvill Jones, G.: Short-term adaptive changes in the human vestibulo-ocular reflex arc. J. Physiol., 256; 361-379, 1976.

24) Gonshor, A. and Melvill Jones, G.: Extreme vestibulo-ocular adaptation induced by prolonged optical reversal of vision. J. Physiol., 256;381$414,1976$.

25) Ito, M., Shiida, T., Yagi, N. and Yamamoto, M.: The cerebellar modification of rabbit's horizontal vestibulo-ocular reflex induced by sustatned head rotation combined with visual stimulation. Proc. Japan Acad., 50; 85-89, 1974.

26) Miles, F.A. and Fuller, I.H.: Adaptive plasticity in the vestibulo-ocular responses of the rhesus monkey. Brain Res., 80; 512-516, 1974.
27) Robinson, D.A.. Adaptive gain control of vestibuloocular refiex by the cerebellum. J. Neurophy., 39; 944-969, 1976.

28) Zee, D.S., Yee, R.D., Cogan, D.G., Robinson, $D . A$. and Engel, W.K.: Ocular motor abnormalities in hereditary cerebellar ataxia. Brain, 99; 207-234, 1976.

29) Westheimer, G. and Blair, S.M.: Functional organization of primate oculomotor system revealed by cerebellectomy. Exp. Brain Res., 21; 463-422, 1974 .

30) Ozawa, T., Naito, M., Takasu, T., Warabi, T. and Yamagami, Y.: Disorders of saccadic eye movement in cerebellar degeneration. Jap. J. Ophthalmol, 18; 363-380, 1974.

31) Wadia, N.H. and Srvami, R.K.: A new form of heredo-familial spinocerebellar degeneration with slow eye movements. Brain, 94; 359-374, 1971.

32) Corvera, J., Torres-Courtney, G. and LopezRios, G.: The neurotological significance of pursuit eye movements and the pendular eye trackirg test. Ann. Otol., 82; 856-867, 1973.

33) Baloh, R.W., Honrubia, V. and Sills, A.. Eyetracking and optokinetic nystagmus. Ann. Otol., $86 ; 108-114,1977$.

本听究は新渴大学耳墺咽喉科学教空（主任: 猪初男教 授〉に执いて行われたすのである、又統計計算は新渴大 学脳研究所神経生理学教室（主任：丸山直湤教授）に拈 いて電算機PDP-12を使用して行われたるのでする。两 教室の方々に厚く感謝致します。

（原稿受付 昭和 52.10.26日)

别剧請冰先 干950新淣市旭町通 1 璠町 754 新鼬大学

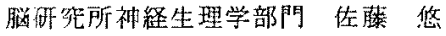

